\title{
Chemical composition and nutritional value of raw and cooked black scabbardfish (Aphanopus carbo)
}

\author{
NARCISA MARIA BANDARRA, IRINEU BATISTA and MARIA LEONOR NUNES \\ Instituto Nacional dos Recursos Biológicos (INRB, I.P./L-IPIMAR), Av. Brasília, 1449-006 Lisboa, Portugal. \\ E-mail: narcisa@ipimar.pt
}

\begin{abstract}
SUMMARY: The objective of the present study was to follow the seasonal chemical changes and to study the effect of culinary treatments on the nutritional value of black scabbardfish (Aphanopus carbo). The proximate chemical composition of black scabbardfish (BSF) landed in Sesimbra (Portugal) was followed for one year. The nutritional quality (proximate chemical composition, amino acid and fatty acid profiles, cholesterol and minerals) of raw, fried and grilled BSF was evaluated in one period of the year. BSF is a semi-fatty species, the protein content was $15-17.5 \%$ and the most abundant amino acids were glutamic acid, aspartic acid and lysine. The dominant fatty acids were monounsaturated (66\%), followed by saturated (19\%) and polyunsaturated $(10 \%)$ ones. Potassium, phosphorus and sodium were the most abundant minerals. Some dehydration occurred in cooked BSF but fat content was the most affected nutrient, particularly in fried fish. These results may suggest that the absorption of frying oil led to important changes in the fatty acid profile, and particularly in the linoleic acid level. The highest protein losses were recorded in fried BSF. In general, the nutritional quality of grilled fish seemed to be more balanced than that of fried fish.
\end{abstract}

Keywords: black scabbardfish, raw, cooked, fatty acids, amino acids, cholesterol and minerals.

RESUMEN: VARIACIÓN ESTACIONAL DE LA COMPOSICIÓN QUÍMICA Y DEL VALOR NUTRITIVO DE SABLE NEGRO (APHANOPUS CARBO) CRUDO Y COCIDO. - El objetivo del presente trabajo fue seguir los cambios químicos y estudiar el efecto de los tratamientos culinarios sobre el valor nutritivo de sable negro (Aphanopus carbo). La composición química proximal de sable negro (BSF) desembarcado en Sesimbra (Portugal) fue seguida durante un año. La calidad nutricional (composición química proximal, perfiles de aminoácidos y ácidos grasos, colesterol y minerales) del pescado crudo, frito y asado fue evaluada en un período del año. BSF es una especie semi-grasa, el contenido de proteína fue de 15 y 17,5\% y los aminoácidos más abundantes fueron glutámico, aspártico y lisina. Los ácidos grasos dominantes fueron los monoinsaturados (66\%), seguidos por saturados (19\%) y polinsaturados $(10 \%)$. Potasio, fósforo y sodio son los minerales más abundantes. Se observó alguna deshidratación en el BSF cocinado, pero el nutriente más afectado fue la grasa, sobre todo en el pescado frito. Estos resultados permiten concluir que la absorción de aceite de freír da lugar a importantes cambios en el perfil de ácidos grasos, en particular en el nivel de ácido linoleico. Las máximas perdidas de proteinas se observaron en el BSF frito. En general, la calidad nutricional del pescado a la parrilla parece estar más equilibrada que la del pescado frito.

Palabras clave: sable negro, crudo, cocido, ácidos grasos, aminoácidos, colesterol, minerales.

\section{INTRODUCTION}

In the last few decades fishing of deep-sea species has become common in several European countries, especially in the North Atlantic (Gordon et al., 2003). As a result, a market has been developed and some products are relatively popular, such as the backs of leafscale gulper shark and Portuguese dogfish (Kjerstad et al., 2003).

Among the deep-sea species, there are very few studies describing the proximate fish muscle composition and the effect of cooking (Brennan and Gormley, 1999; Gormley et al., 1994; Maier et al., 1997; $\varnothing \mathrm{kland}$ et al., 2005). In addition, concerns are often 
raised about the presence of contaminants (Ruiter, 1995; Afonso et al., 2008). Thus, the gathering of available knowledge, the development of studies about the biochemical composition and the dissemination of such information towards the processors and consumers is of utmost importance for the upgrading of these species.

In Portugal, the black scabbardfish (Aphanopus carbo Lowe, 1839) (BSF) is the most important commercially exploited fish of Portuguese deepwater fisheries. In the last decade landings have increased to about 6000 tonnes (3000 tonnes each off Madeira and mainland Portugal). This species is available as fresh gutted fish, fillets and portions and frozen fillets, and BSF now plays an important role in the human diet of the Madeira Islands and Sesimbra (Portugal mainland). Moreover, in recent years it has gained an important role in Portuguese gastronomy through the preparation of very special dishes.

As for other fish species, the chemical composition of BSF flesh is influenced by a number of factors, but culinary treatments are also responsible for major changes in fish muscle, especially affecting sensory attributes, chemical characteristics and nutritional composition.

The aim of this study was to characterise the seasonal changes in proximate chemical composition of fillets with and without white skin, to evaluate the nutritional aspects of the flesh (main constituents, amino acid and fatty acid profiles, and cholesterol, mineral and vitamin contents) and to determine the effect of grilling and frying on its biochemical composition.

\section{MATERIALS AND METHODS}

\section{Sample preparation and cooking}

Black scabbardfish (BSF) caught off Sesimbra (Portugal) in 2007-2008 (Fig. 1) was obtained from a local retailer. Samples were transported in ice to the laboratory in Lisbon. For seasonal chemical characterisation, 10 individuals were analysed on a routine monthly basis. On arrival at the laboratory, fresh fish was hand processed, i.e. filleted and skinned (removal of the thin black skin). Two lots of fillets were prepared: one (skin on) with the white skin (the one under the black skin) and one (skin off) without the skin. All fish in each lot were homogenised. Fish for

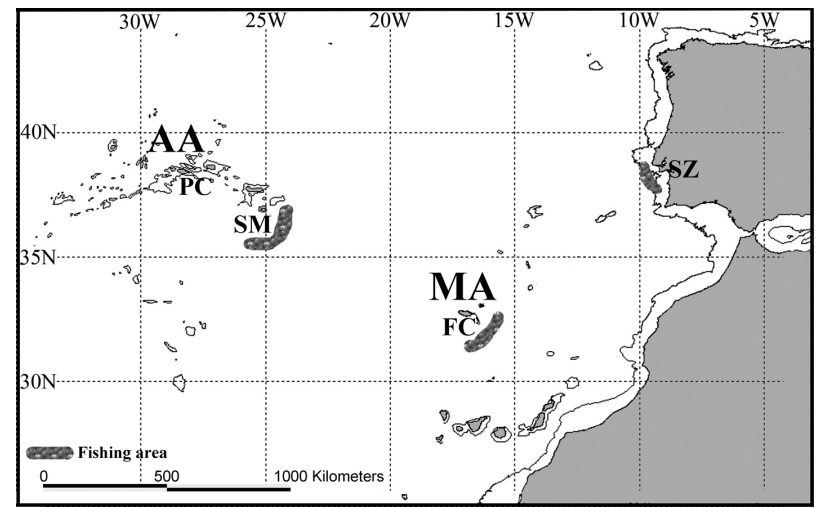

FIG. 1. - Map of the southern northeast Atlantic with the sampling locations of black scabbardfish and the $1000 \mathrm{~m}$ isobath. AA, Azores Archipelago; FC, Funchal; MA, Madeira Archipelago; PC, Pico Island: SM, Santa Maria Island; SZ, Sesimbra (mainland Portugal).

nutritional characterisation and culinary treatments was also filleted and skinned by hand (only the black skin was removed). Culinary treatments followed the usual household preparation. For grilling, fish portions (about $7 \mathrm{~cm}$ length) were previously spiked with $1.5 \%$ salt, which was partially removed after 15 minutes; grilling was done in an electric grill (2000 W) for 10 minutes. For frying, fish portions were prepared and salted as for grilling, then coated with wheat flour and deep-fried in vegetable oil (total saturated fatty acids $10 \%$, total monounsaturated fatty acids $29 \%$, total polyunsaturated fatty acids $61 \%$ ). The oil was discarded after each batch frying. All assays were conducted in triplicate samples and the results are expressed in wet weight.

\section{Analytical methods}

In this study we analysed the concentration of the different nutritional components in raw, fried and grilled muscle. The results are expressed in $\mathrm{g}$ per $100 \mathrm{~g}$ wet weight of raw, fried or grilled muscle, respectively. Moisture, ash, protein and lipid contents were determined in each specimen's tissue according to the Association of Official Analytical Chemists procedures (AOAC, 2000). Briefly, the moisture content was obtained by drying the sample overnight at $105^{\circ} \mathrm{C}$, ash was quantified after combustion for 16 $\mathrm{h}$ at $550^{\circ} \mathrm{C}$, crude protein content was determined by the Kjeldahl method (AOAC, 2000) using a conversion factor of 6.25 , and total lipid was determined with the Soxhlet extraction method (AOAC, 2000) using ethyl ether. The energy value, expressed as $\mathrm{kcal}$ and $\mathrm{kJ} / 100 \mathrm{~g}$ edible part, was estimated using FAO (1989) factors: 9.02 and $4.27 \mathrm{kcal} / \mathrm{g}$ for fat and protein, respectively. 
The amino acid profile was determined by ion exchange chromatography of hydrolysed proteins (6 $\mathrm{N}$ hydrochloric acid containing $0.1 \%$ phenol) in an MLS-1200 Mega Microwave System (Milestone) at $800 \mathrm{~W}$ and $160^{\circ} \mathrm{C}$ for $10 \mathrm{~min}$. The hydrolysis was performed under inert and anaerobic conditions to prevent oxidative degradation of amino acids. The hydrolysates were filtered and dissolved in $\mathrm{pH} 2.2$ sodium citrate buffer. It is noteworthy that with this hydrolysis procedure tryptophan was not determined. Amino acids were separated by ion exchange liquid chromatography in a Biochrom 20 automatic analyser (Amersham Biosciences) equipped with a column filled with a polysulphonated resin $(250 \mathrm{x}$ $4.6 \mathrm{~mm}$ ), using three sodium citrate buffers, $\mathrm{pH} 3.20$, 4.25 and 6.45 (Amersham Biosciences), and three different temperatures $\left(50^{\circ} \mathrm{C}, 58^{\circ} \mathrm{C}\right.$ and $\left.95^{\circ} \mathrm{C}\right)$. The detection of amino acids was done at $440 \mathrm{~nm}$ and $570 \mathrm{~nm}$ after reaction with ninhydrin (Amersham Biosciences). Amino acids were identified by comparison of their retention time with those of specific standards (Sigma) and quantified with the software EZChrom $^{\mathrm{TM}}$ Chromatography Data System, version 6.7. (Scientific Software Inc.) using norleucine (Sigma) as an internal standard.

The determination of fatty acid profile methyl esters was based on the experimental procedure described by Lepage and Roy (1986), modified by Cohen et al. (1988). The fatty acid methyl esters were analysed in a CP 3800 Varian gas chromatograph, equipped with an auto-sampler and fitted with a flame ionisation detector (FID). The separation was carried out with helium as the carrier gas in a DBWax polyethylene glycol column ( $30 \mathrm{~m} \times 0.25 \mathrm{~mm}$ id) programmed to start at $180^{\circ} \mathrm{C}$ for $5 \mathrm{~min}$, heat at $4^{\circ} \mathrm{C} / \mathrm{min}$ for $10 \mathrm{~min}$ and hold up at $220^{\circ} \mathrm{C}$ for $25 \mathrm{~min}$, with a detector at $250^{\circ} \mathrm{C}$. A split injector $(100: 1)$ at $250^{\circ} \mathrm{C}$ was used. Fatty acid methyl esters were identified by comparison of their retention time with those of chromatographic Sigma standards. The values were expressed as $\mathrm{mg} / 100 \mathrm{~g}$ edible part, using the conversion factors proposed by Weihrauch et al. (1977). The total unsaturation index (UI) was generated by summing the individual fatty acid unsaturation indices, which were calculated by multiplying the number of double bonds of each fatty acid by its percentage and dividing by 100 (Huynh and Kitts, 2009).

Cholesterol was assayed by gas chromatography after saponification in alkaline conditions, based on the method of Naemmi et al. (1995) modified by Oehlenschläger (2000). It was analysed in a Cx 3400
VARIAN gas chromatograph and the separation was carried out with helium as the carrier gas in an HP5 column ( $30 \mathrm{~m} \times 0.5 \mathrm{~mm}$ id). The temperatures of the oven, injector and detector were $280^{\circ} \mathrm{C}, 285^{\circ} \mathrm{C}$ and $300^{\circ} \mathrm{C}$, respectively. Cholesterol was identified and quantified by comparison with a pure standard (Sigma, Portugal) from which a calibration curve was prepared.

Calcium and magnesium were measured by flame atomic absorption spectrometry in the ash hydrochloric solution, and using lanthanum as the releasing agent (AOAC, 2000). Chloride was determined by a volumetric method (IPQ, 1988) after precipitation of chloride with a silver nitrate solution in excess and titration of the excess with ammonium thiocyanate in the presence ferric indicator. Copper, iron and zinc were analysed by flame atomic absorption spectrophotometry in the ash hydrochloric solution (AOAC, 2000). Manganese was determined in an ash nitric solution by atomic absorption spectrometry equipped using a graphite furnace (AOAC, 2000). Phosphorus was analysed by spectrophotometry, after reaction of molybdovanadate reagent with the ash hydrochloric solution (AOAC, 2000). Potassium and sodium were quantified by flame photometry in the ash hydrochloric solution, using lithium solution as an ionisation buffer (AOAC, 2000). All results are expressed as $100 \mathrm{~g}$ of edible part.

The thrombogenic potential of the fish studied was evaluated according to Ulbricht and Southgate (1991) using the thrombogenic index [TI $=(14: 0+$ $16: 0+18: 0) /(0.5$ MUFA + 0.5 n-6 PUFA + 3 n-3 PUFA + n-3 PUFA/n-6 PUFA]. For TI calculations the fatty acids concentrations were expressed as $\mathrm{g} / 100 \mathrm{~g}$ of total fatty acids. The hypercholesterolemic-atherogenic potential of the samples was evaluated using the cholesterol-saturated fat index (CSI) according to Connor et al. (1986), where CSI $=(1.01$ $\times \mathrm{g}$ of SFA $100 \mathrm{~g}^{-1}$ of fresh matter $)+(0.05 \times \mathrm{mg}$ of cholesterol $100 \mathrm{~g}^{-1}$ of fresh matter).

\section{Statistical analysis}

One-way analysis of variance (ANOVA) was used to compare biochemical compositions. Normality and homogeneity of variances were verified by Kolmogorov-Smirnov and Bartlett tests, respectively. A paired t-test was used to compare the apparent retention factors. All statistical tests were performed using the Statistics Version 6.0 for Windows XP (Microsoft, USA) package. 


\section{RESULTS}

\section{Raw material}

The average values of the four main constituents-moisture, fat, protein and ash - and the energy values in black scabbardfish fillets with (skin-on) and without white skin (skinless) are shown in Table 1 and the seasonal changes of these four compounds over one year are shown in Figures 2 and 3. The moisture content (\% wet weight) was lower in skinon fillets $(75.3 \%)$ than in skinless fillets $(79.0 \%)$. The crude protein content was of the order of $16.0 \%$ and the ash between $1.1 \%$ and $1.2 \%$. As can be seen, the total lipid content was always higher in skin-on fillets $(6.7 \%)$ than in skinless products $(2.5 \%)$, due to the removal of a thin layer of subcutaneous fat during the skinning. The energy values were low, 95 and $129 \mathrm{kcal} / 100 \mathrm{~g}$ for skinless and skin-on fillets, respectively.

The amino acid profile $(\mathrm{g} / 100 \mathrm{~g}$ protein) of this species, that of a standard (FAO/WHO, 1991) and the recommended daily intakes (Usydus et al., 2009)

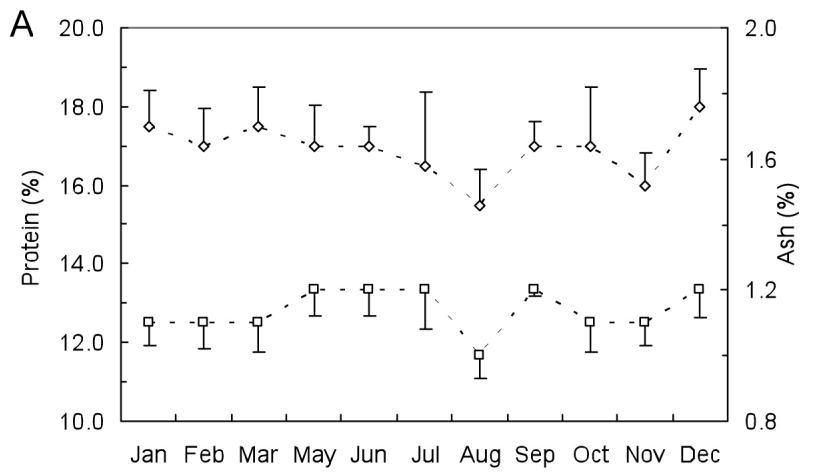

- - - - Protein (\%) - - - - Ash (\%)

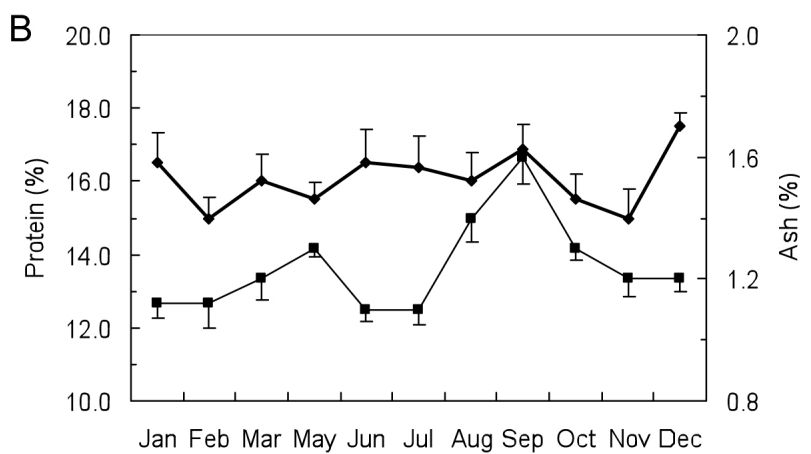

Protein $(\%) \rightarrow-$ Ash $(\%)$

FIG. 2 - Seasonal evolution of protein and ash content in black scabbardfish fillets (A, skin-on; B, skinless).
TABLE 1. - Proximate chemical composition (\% wet weight; mean \pm standard deviation) and energy values (kcal/100 g wet weight; mean \pm standard deviation) of skin-on and skinless black scabbardfish fillets.

\begin{tabular}{lrr}
\hline & Skinless fillets & Skin-on fillets \\
\hline Moisture $(\%)$ & $79.0 \pm 1.8$ & $75.3 \pm 2.3$ \\
Fat $(\%)$ & $2.5 \pm 1.2$ & $6.7 \pm 2.7$ \\
Protein $(\%)$ & $16.9 \pm 0.7$ & $16.1 \pm 0.8$ \\
Ash $(\%)$ & $1.1 \pm 0.1$ & $1.2 \pm 0.2$ \\
Energy (kcal/100 g) & $94.7 \pm 14.2$ & $129.2 \pm 17.8$ \\
\hline
\end{tabular}

are shown in Table 2. The protein of this species contained high amounts of non-essential amino acids (NEAA) such as glutamic acid, aspartic acid and alanine: $15.29,10.19$ and $6.37 \mathrm{~g} / 100 \mathrm{~g}$ of protein, respectively. The main essential amino (EAA) acids were lysine and leucine, accounting for 10.19 and $8.28 \mathrm{~g} / 100 \mathrm{~g}$ of protein, respectively. Within semiessential amino acids (SEAA), arginine was the most abundant $(6.37 \mathrm{~g} / 100 \mathrm{~g}$ of protein). The main fatty acids (FA) detected in the total lipids of black scabbardfish are shown in Table 4 . The saturated fraction (SFA) represented $19.4 \%$ of total fatty acids, with

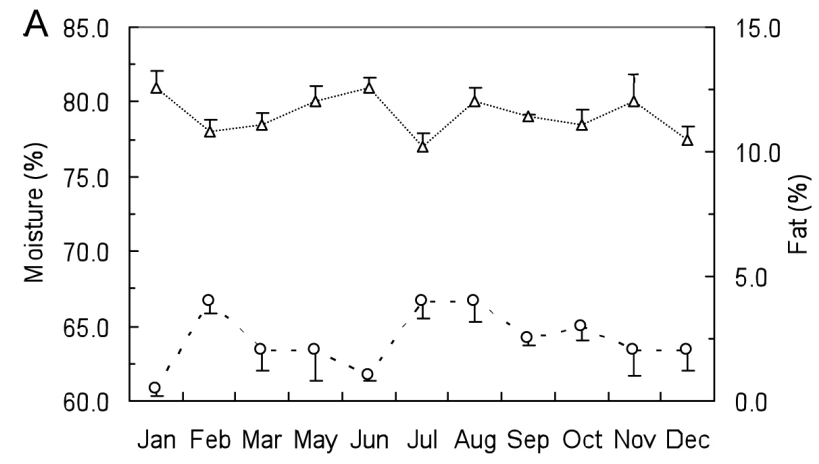

$\Delta \cdots \cdots \cdots$ Moisture (\%) - - - - Fat (\%)

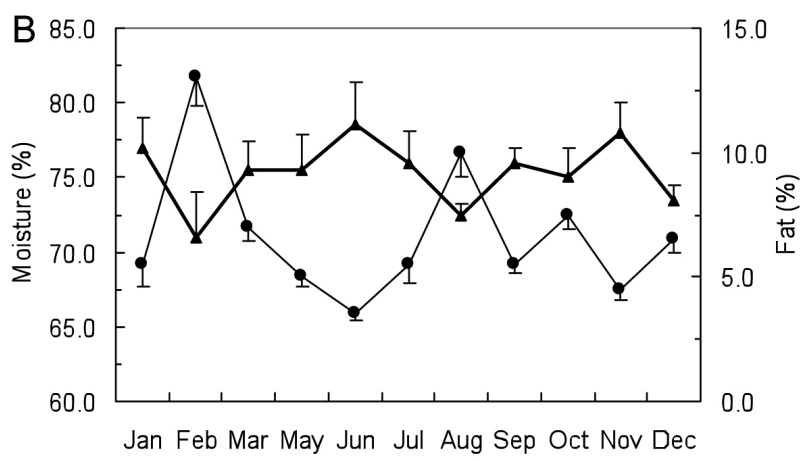

Moisture (\%) $\bullet-$ Fat $(\%)$

FIG. 3 - Seasonal evolution of moisture and fat content in black scabbardfish fillets (A, skin-on; B, skinless). 
TABLE 2. - Amino acid composition ( $\mathrm{g} / 100 \mathrm{~g}$ protein; mean \pm standard deviation) of black scabbardfish edible part, protein standard and human recommended daily intake.

\begin{tabular}{|c|c|c|c|}
\hline Amino acid & $\begin{array}{l}\text { Content } \\
\text { (g/100 g } \\
\text { protein) }\end{array}$ & $\begin{array}{l}\text { Protein standard }{ }^{1} \\
(\mathrm{~g} / 100 \mathrm{~g} \\
\text { protein })\end{array}$ & $\begin{array}{l}\text { Recommended } \\
\text { daily intake } \\
(\mathrm{mg} / \mathrm{kg} \\
\text { body weight })^{2}\end{array}$ \\
\hline \multicolumn{4}{|l|}{ EAA and SEEA } \\
\hline Threonine & $4.46 \pm 1.26$ & 3.4 & 6.5 \\
\hline Valine & $5.73 \pm 0.98$ & 3.5 & 11.4 \\
\hline Methionine & $3.18 \pm 0.45$ & $2.5^{\mathrm{a}}$ & $12.1^{\mathrm{a}}$ \\
\hline Isoleucine & $5.10 \pm 0.57$ & 2.8 & 15.7 \\
\hline Leucine & $8.28 \pm 1.35$ & 6.6 & 9.5 \\
\hline Phenylalanine & $3.82 \pm 0.50$ & $6.3^{\mathrm{b}}$ & $12.1^{\mathrm{b}}$ \\
\hline Lysine & $10.19 \pm 1.85$ & 5.8 & 9.4 \\
\hline Histidine & $1.91 \pm 0.43$ & & \\
\hline Arginine & $6.37 \pm 0.00$ & & \\
\hline Serine & $3.82 \pm 0.49$ & & \\
\hline$\Sigma$ EAA & $40.8 \pm 6.80$ & $32.0^{\mathrm{c}}$ & 79.6 \\
\hline$\Sigma$ SEAA & $12.1 \pm 2.33$ & & \\
\hline \multicolumn{4}{|l|}{ NEAA } \\
\hline Aspartic acid & $10.19 \pm 2.10$ & & \\
\hline Glutamic acid & $15.29 \pm 1.87$ & & \\
\hline Glycine & $5.10 \pm 0.45$ & & \\
\hline Alanine & $6.37 \pm 0.43$ & & \\
\hline Tyrosine & $3.82 \pm 0.29$ & & \\
\hline Proline & $5.10 \pm 0.28$ & & \\
\hline$\Sigma$ NEAA & $45.9 \pm 4.92$ & & \\
\hline
\end{tabular}

${ }^{1}$ FAO/WHO (1991); ${ }^{2}$ (Usydus et al., 2009).

EAA-Essential amino acids; SEEA-Semi essencial amino acids; NEAA-Non essential amino acids. ${ }^{\mathrm{a}}$ Methionine+Cysteine;

${ }^{\mathrm{b}}$ Phenylalanine+Tyrosine; ${ }^{\mathrm{c}}$ including Tryptophan.

palmitic acid (16:0) as the most important FA within this fraction, followed by stearic acid (18:0).

Monounsaturated fatty acids (MFA) were the main group, at over $65 \%$. Oleic acid (18:1n-9) was the dominant one, followed by $22: 1$ and $20: 1$. The presence of nervonic acid (24:1n-9) was recorded. Polyunsaturated fatty acids (PUFA) were the smallest group and the n-3 PUFA was the dominant one compared with n-6 PUFA, showing an $n-3 / n-6$ ratio of 8.8. Eicosapentaenoic acid (EPA, 20:5n-3) and docosahexaenoic acid (DHA, 22:6n-3) represented around $80 \%$ of total PUFA and DHA accounted for over $59 \%$.

The mineral content and range observed for potassium $(\mathrm{K})$, phosphorus $(\mathrm{P})$, sodium $(\mathrm{Na})$, sulphur $(\mathrm{S})$, magnesium $(\mathrm{Mg})$, calcium $(\mathrm{Ca})$, zinc $(\mathrm{Zn})$, copper $(\mathrm{Co})$ and chloride $(\mathrm{Cl})$ are given in Table 3. As can be seen, potassium and phosphorus were the most abundant.

\section{Cooked products}

Values related to raw BSF and cooked productschemical composition, energetic value, main fatty acids, cholesterol and minerals - are shown in Table 5.
TABLE 3. - Mineral content (mg/100 g wet weight muscle; mean \pm standard deviation), range of black scabbardfish muscle and recommended daily intakes (RDI).

\begin{tabular}{lccc}
\hline Elements & $\begin{array}{c}\text { Content } \\
(\mathrm{mg} / 100 \mathrm{~g} \text { WWM })\end{array}$ & Range & RDI \\
& & & \\
\hline Macroelements & & & \\
Potassium (K) & $296.6 \pm 55.0$ & $215.3-432.6$ & $4700 \mathrm{mg}$ \\
Phosphorous (P) & $175.9 \pm 22.0$ & $163.2-185.6$ & $700 \mathrm{mg}$ \\
Sodium (Na) & $156.8 \pm 50.2$ & $103.8-273.7$ & $1500 \mathrm{mg}$ \\
Sulphur (S) & $124.2 \pm 33.6$ & $74.7-171.8$ & $\mathrm{NS}$ \\
Chloride (Cl) & $121.8 \pm 27.3$ & $86.5-163.7$ & $2300 \mathrm{mg}$ \\
Magnesium (Mg) & $28.0 \pm 1.8$ & $24.6-29.9$ & $(413-316) \mathrm{mg}$ \\
Calcium (Ca) & $11.9 \pm 3.7$ & $7.6-17.9$ & $1000 \mathrm{mg}$ \\
& & & \\
Trace elements & & & $(11-8) \mathrm{mg}$ \\
Zinc (Zn) & $0.27 \pm 0.02$ & $0.25-0.30$ & $900 \mu \mathrm{g}$ \\
Copper (Cu) & $0.06 \pm 0.02$ & $0.01-0.17$ & \\
\end{tabular}

Values in brackets for $\mathrm{Mg}$ and $\mathrm{Zn}$ refer to differences in genders: the first and second values correspond to male and female, respectively. NS, has not been set.

TABLE 4. - Main fatty acids (relative area percentage of total fatty acids) in lipids of black scabbardfish muscle, SFA (saturated fatty acids), MUFA (monounsaturated fatty acids), PUFA (polyunsaturated fatty acids), FA (fatty acids).

\begin{tabular}{|c|c|}
\hline Fatty acids ( $\%$ of total FA) & Raw muscle \\
\hline $\begin{array}{l}14: 0 \\
15: 0 \\
16: 0 \\
17: 0 \\
18: 0 \\
20: 0 \\
\sum \text { SFA }^{a}\end{array}$ & $\begin{array}{r}2.12 \pm 0.078 \\
0.38 \pm 0.021 \\
12.20 \pm 0.247 \\
0.34 \pm 0.006 \\
4.24 \pm 0.070 \\
0.03 \pm 0.030 \\
19.36 \pm 0.340\end{array}$ \\
\hline $\begin{array}{l}16: 1 n-7 \\
17: 1 \\
18: 1 n-9 \\
18: 1 n-7 \\
20: 1 n-9 \\
22: 1 n-11 \\
24: 1 n-9 \\
\sum \text { MUFA }^{a}\end{array}$ & $\begin{array}{r}3.26 \pm 0.050 \\
0.24 \pm 0.205 \\
26.06 \pm 0.172 \\
6.28 \pm 0.249 \\
14.10 \pm 0.187 \\
15.48 \pm 0.326 \\
0.19 \pm 0.031 \\
65.67 \pm 0.418\end{array}$ \\
\hline $\begin{array}{l}18: 2 n-6 \\
18: 4 n-3 \\
20: 2 n-6 \\
20: 5 n-3 \\
22: 5 n-3 \\
22: 6 n-3 \\
\sum \text { PUFA }^{a} \\
\sum n-3 F^{a} \\
\sum n-6 F^{a}\end{array}$ & $\begin{array}{l}1.09 \pm 0.256 \\
0.11 \pm 0.087 \\
0.14 \pm 0.248 \\
1.94 \pm 0.066 \\
0.84 \pm 0.079 \\
5.65 \pm 0.303 \\
9.51 \pm 1.870 \\
8.54 \pm 0.352 \\
0.97 \pm 0.619\end{array}$ \\
\hline $\begin{array}{l}\text { Ratio n-3/n- } 6^{a} \\
\text { Other FA }{ }^{b}\end{array}$ & $\begin{array}{l}8.80 \pm 1.30 \\
5.46 \pm 1.12\end{array}$ \\
\hline
\end{tabular}

STD - Standard deviation $(n=5)$.

a Data relative to the total FA identified.

b Traces and unidentified

Culinary treatments strongly affected the moisture content $(\mathrm{P}<0.05)$. The protein levels of raw, grilled and fried products were also significantly different $(\mathrm{P}<0.05)$. Fat values were significantly higher in fried products $(16.6 \%)$ than in raw products $(2.8 \%)$ and grilled products $(3.2 \%)$. The fat content in fried 
TABLE 5. - Nutritional data of raw, fried and grilled black scabbardfish (mean \pm standard deviation).

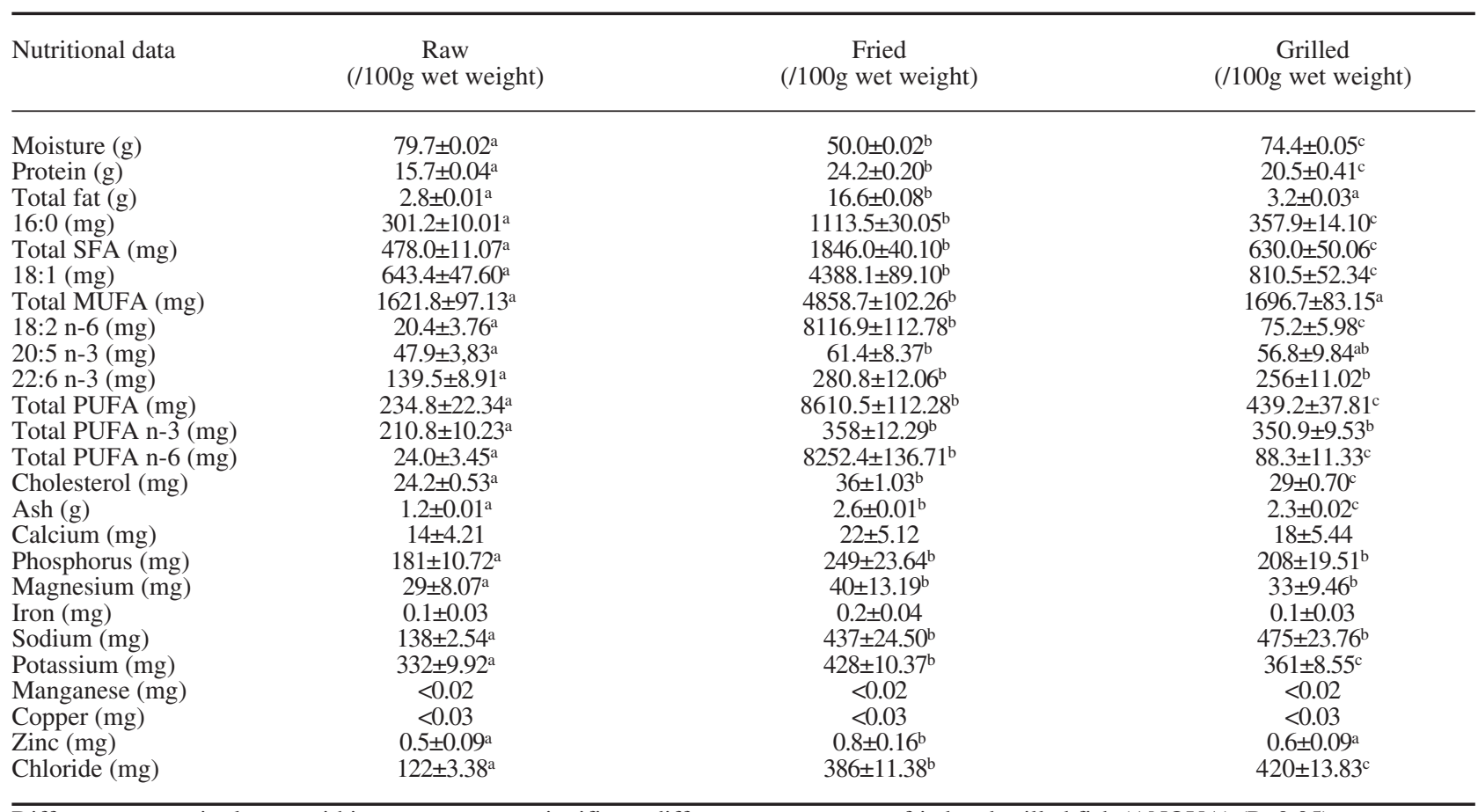

Different superscript letters within rows represent significant differences among raw, fried and grilled fish (ANOVA) $(\mathrm{P}<0.05)$.

products reflected the absorption of frying oil. Ash almost doubled in fried and grilled products in comparison with raw BSF $(\mathrm{P}<0.05)$.

Relatively to the fatty acids contents, the main changes were due to absorption of vegetable oil and the leaching out of water. The absorption of frying oil was also well evidenced in the considerable increase in MUFA and PUFA as a result of the absorption of oleic and linoleic acids, respectively. The cholesterol contents in raw, grilled and fried products were 24 , 29 and $36 \mathrm{mg} / 100 \mathrm{~g}$, respectively.

The most relevant minerals in cooked products were potassium, phosphorus and sodium (Table 5). The main changes were due to water loss and the addition of salt before cooking.

\section{DISCUSSION}

\section{Raw material}

It is well known that the chemical composition of fish muscle varies according to sex, age, environment and season (Love, 1980). In the present study only the seasonal effect and the presence of white skin was studied. The reason for characterising the fillets with white skin on was that this is the usual form of household use in fish dishes. The results in
Table 1 and Figures 1 and 2 allow us to conclude that black scabbardfish is a semi-fatty species because its fat content is between 5 and $10 \%$. A negative correlation between fat and moisture was observed in the present study (results not shown), as has been reported for a number of fish species (Love, 1980; Suzuki, 1981). These seasonal lipid changes are usual in fish and depend on factors such as time of year (Dawson and Grimm, 1980), environmental conditions (Gill and Weatherly, 1984), stage of maturity of the gonads (Weatherley and Gill, 1987), state of nutrition (Elliot, 1976; Corraze, 2001) and age (Parker and Vanstone, 1966). The stage of maturity is one of the most important factors because during gonadal maturation stored lipids or muscle proteins are mobilised to gonads (Sharer, 1994). A decreasing trend of BSF fat content (Fig. 3A) in the period from July to January was observed; Neves et al. (2009) found an increase of the gonadal maturation percentage in the period between July and November, suggesting an inverse relation between lipid content and sexual maturation in this species.

The protein and ash contents were in the range found for most deep water fish species, such as silver scabbardfish (Bandarra et al., 2004) a species belonging to the same family of BSF. The amino acid composition of the edible part of black scabbardfish was similar to that of other deep-water fish 
species (Bandarra et al., 2004). The essential amino acids values allow us to conclude that the protein of this species is well balanced, since the amounts were greater than those in the standard protein $(\mathrm{FAO} /$ WHO, 1991), as can be seen in Table 2. In addition, limiting amino acids in black scabbardfish, such as lysine and methionine, expressed as $\mathrm{g}$ per $100 \mathrm{~g}$ of protein, also occurred at levels higher than those in the standard protein (FAO/WHO, 1991). The total of SEAAs in BSF is substantial (12.1 g/100 g protein), namely arginine. These amino acids are not normally required in the human diet but must be exogenously supplied to specific populations under special conditions, such as intensive growth, stress, or in some diseases state. As in most fish species, the most important NEAAs were glutamic and aspartic acid. The amounts of the amino acids cysteine and tryptophan were not determined, but they would sum about $1.28 \mathrm{~g}$ per $100 \mathrm{~g}$ of black scabbardfish protein. The essential amino acid requirement for an adult man weighing $70 \mathrm{~kg}$ is about $5.6 \mathrm{~g}$ per day (Usydus et al., 2009). Therefore, this fish species can be considered a significant source of amino acids in terms of both quality and quantity, because $100 \mathrm{~g}$ of the edible part is sufficient to meet this daily requirement.

The influence of diet on the fatty acid profile has been recognised and may thus be related to the stomach contents. However, in the case of black scabbardfish the stomach is frequently empty or everted and it was not possible to analyse any remains in the stomach. Therefore, the discussion takes into account the fatty acid profile of species living in deep-sea waters in the NE Atlantic. In most fish species the omega 3 polyunsaturated fatty acids (n-3 PUFA) are the dominant group, but in BSF the monounsaturated fatty acids were the largest fraction. This exception has also been found for meagre and silver scabbardfish (Nunes et al., 2003) and for sablefish (Oliveira et al., 2008). In BSF oleic acid was the dominant monounsaturated fatty acid, and the percentage of 18:1n-9 and 18:1n-7 isomers was higher than $30 \%$ of the total of fatty acids, which is an unusual result in fatty acid profiles of fish species (Bandarra et al., 2004). It is also important to note that relevant percentages of $20: 1$ and $22: 1$ were recorded, contrary to the findings of Sirot $e t$ al. (2008) in more than fifty species. This difference is probably related to the feed available because its exogenous origin is recognised (Ackman, 1982). The high MUFA percentage found in BSF may result from the assimilation of fatty alcohols from the wax esters of the prey, which are directly converted into fatty acids, as also mentioned by Stowasser et al. (2009) for Coryphaenoids armatus, a deep-sea fish living at depths of 2500 to 4800 $\mathrm{m}$. The unsaturation index (UI) of total unsaturated fatty acids and the unsaturation index of only EPA + DHA in the lipids of BSF were 1.27 and 0.44, respectively. These values are much lower than those reported by Huynh and Kitts (2009) for species with a similar fat content as a result of the high level of MUFA in BSF.

The presence of nervonic acid (24:1n-9) is not usually detected in most fish species, but in BSF it was about $0.2 \%$. Ota et al. (1995) also reported the presence of this fatty acid in flathead flounder lipids and Shanta and Ackman (1991) in nine different marine fish oils. The results obtained by the latter authors support the hypothesis that nervonic acid is biosynthesised by fish. Thus, the presence of this fatty acid in BSF suggests that this species is able to biosynthesise this MUFA. The importance of nervonic acid was highlighted by_Seargent et al. (1994), who demonstrated some medicinal significance based on its essential role as a nutrient for growth, development and maintenance of the brain. Within the saturated group, palmitic acid was the most abundant, with a level of $12 \%$. This fatty acid is quite constant over the life cycle of marine animals and is considered a key metabolite in the synthesis of other fatty acids (Ackman, 1982).

Although BSF has an unusual fatty acid profile due to its high MUFA percentage and low PUFA content, it has to be stressed that the $n-3 / n-6$ ratio found in BSF falls within the range reported by Huynh and Kitts (2009) for several fish species. Moreover, the percentage of EPA and DHA of the total n-3 PUFA was similar to that reported by the previous authors. This similar percentage of n-3 fatty acids of total PUFA among several species living in quite different habitats shows its importance in the structural lipid fraction.

The average mineral content in the edible part was very close to $1.1 \mathrm{~g} / 100 \mathrm{~g}$ though, as can be seen in Table 4, great variations between individuals were found. The order in terms of amounts was: potassium $>$ phosphorus $>$ sodium $>$ sulphur $>$ chloride $>$ magnesium $>$ calcium $>$ zinc $>$ copper. As in most species, potassium was the most abundant mineral. Considering the daily intake recommendations, the edible part of black scabbardfish is a good source of several minerals. 


\section{Cooked products}

The proximate chemical composition of fried and grilled BSF showed that both cooking methods resulted in water loss, tough the greatest loss was observed in frying. The higher protein level recorded in fried BSF in comparison with the other two methods was also observed by Türkkan et al. (2008) in fried, beheaded and eviscerated sea bass (Dicentrarchus labrax). The water loss that occurred during frying was responsible for this apparent higher concentration. Furthermore, the high fat content of fried fish reflects the absorption of oil (Table 5). The use of wheat flour to cover fish before frying contributes to an additional uptake of oil. The water loss and the higher contents of the other constituents in the cooked fish are in accordance with the findings of other studies (Gall et al., 1983; García-Arias et al., 2003; Gokoglu et al., 2004; Kalogeropoulos et al., 2004; Rosa et al., 2007). Limited changes in the fat content of BSF occurred during grilling, probably due to the preferential location of lipids in membranes. This is particularly evidenced by the higher level of PUFAs, especially DHA (an important structural fatty acid), which were not lost during grilling.

The absorption of the vegetable oil by fish during frying was responsible for the high level of MUFA and PUFA, because frying oil was very rich in oleic and linoleic acids. The intake of vegetable oil by fish is clearly evidenced by the amounts of these two fatty acids in the fried BSF. The absorption of vegetable oil during frying led to an important decrease in the $n-3 / n-6$ ratio, which is in agreement with previous findings (Echarte et $a l ., 2001)$. In fact, the $\mathrm{n}-3 / \mathrm{n}-6$ ratio in grilled fish was 4.0 , whereas in fried fish it was only 0.04 , indicating that grilled fish provides higher levels of n-3 fatty acids. However, the thrombogenic index calculated for fried and grilled fish showed very similar levels: 0.22 and 0.18 , respectively. It is also to be stressed that a dose of $150 \mathrm{~g}$ of fried BSF or grilled BSF can provide $513.2 \mathrm{mg}$ or $469.2 \mathrm{mg}$ of EPA plus DHA respectively, which are close to the daily dose $(500 \mathrm{mg})$ recommended by the ISSFAL (2004) to prevent cardiovascular diseases.

The water lost during grilling and frying were also reflected in the relative increase in cholesterol level in the cooked products. This effect was also particularly evident in fried BSF and has been reported for other fish species (Ewaida, 1993; Echarte et al., 2001).
The CSI was calculated for raw, fried and grilled BSF because it has been used to compare different foods in terms of their hypercholesterolaemic-atherogenic potential (Connor et al., 1986). This index was 1.68, 3.66 and 2.09 for raw, fried and grilled fish, respectively. Both culinary treatments, and particularly frying, led to an increase in this index. However, the levels attained in the present study were considerably lower than those reported by Kalogeropolous et al. 2004, who used olive oil as the frying medium. It should be stressed that both raw and cooked BSF had a cholesterol level considerably below the maximum recommended daily intake (RDI), which is $200-300 \mathrm{mg}$.

The rise in the ash content in cooked products was influenced by the addition of salt and by the water loss during the culinary treatments. Higher levels of calcium, phosphorus, magnesium, potassium and zinc in fried than in grilled fish also reflect the higher water loss during frying. The very high level of sodium and chloride resulted from the addition of sodium chloride to fish during its culinary preparation.

The results obtained by Gokoglu et al. (2004) in rainbow trout and by Rosa et al. (2007) and Ersoy and Özeren (2009) in African catfish did not show similar trends between the effect of frying and grilling on the mineral fraction, which may be related to the specific characteristics of each fish species and/or to the procedure followed in each culinary treatment.

Finally, taking into consideration the RDI values indicated in Table 3, a dose of $150 \mathrm{~g}$ provides a good contribution of minerals to satisfy human requirements.

\section{REFERENCES}

Ackman, R.G. - 1982. Fatty acid composition of fish oils. In: S.M. Barlow and M.E. Stansby (eds.), Nutritional Evaluation of Long-Chain Fatty Acids in Fish Oils, p. 25, Academic Press, London.

Afonso, C., H.M. Lourenço, C. Pereira, M.F. Martins, M.L. Carvalho, M. Castro and M.L. Nunes. - 2008. Total and organic mercury, selenium and $\alpha$-tocopherol in some deep-water fish species. J. Sci. Food Agric., 88: 2543-2550.

AOAC. - 2000. Official Methods of Analysis of AOAC International, 17th Edition. William Horwitz (ed.). AOAC International, $2200 \mathrm{p}$.

Bandarra, N.M., M.A. Calhau, L. Oliveira, M. Ramos, M.G. Dias, H. Bartolo, M.R. Faria, M.C. Fonseca, J. Gonçalves, I. Batista and M.L. Nunes. - 2004. Composição e valor nutricional dos produtos da pesca mais consumidos em Portugal. Publ. Avulsas IPIMAR, 11: 1-103.

Brennan, M.H. and T.R. Gormley. - 1999. The quality of underutilized deep-water fish species. Tegasc (Irish Agriculture and 
Food Development Authority). Res. Rep. n²2

Cohen, Z., A. Vonshak and A. Richmond. - 1988. Effect of environmental conditions on fatty acid composition of the red algae Porphyridium cruentum: correlation to growth rate. J. Phycol., 24: $328-332$

Connor, S.L., J.R Gustafson and S.M Artaud-Wild. - 1986. The cholesterol/saturated-fat index: an indication of the hypercholesterolaemic and atherogenic potential of food. Lancet, 327 $1229-1232$.

Corraze, C. - 2001. Lipid Nutrition. In: J. Guillaume, S. Kaushik, P. Bergot, R. Métailler (eds.), Nutrition and Feeding of Fish and Crustaceans, pp 111-130. Praxis Publishing Ld, Chichester UK.

Dawson, A.S. and A.S. Grimm. - 1980. Quantitative seasonal changes in the protein, lipid and energy content of the carcass, ovaries and liver of adult female plaice, Pleuronectes platessa L. J. Fish Biol., 16: 493-504.

Echarte, M., M.A. Zulet and I. Astiasaran. - 2001. Oxidation process affecting fatty acids and cholesterol in fried and roasted salmon. J. Agr. Food Chem., 49: 5662-5667.

Elliot, J.M. - 1976. Body composition of brown trout (Salmo trutta) in relation to temperature and ration size. J. An. Ecol., 45: 273-289.

Ersoy, B. and A. Özeren. - 2009. The effect of cooking methods on mineral and vitamin contents of African catfish. Food Chem. 115: 419-422.

Ewaida, E.H. - 1993. Cholesterol, fat and food energy content of selected raw and cooked commercial fish species from the Arabian Gulf. Ecol. Food Nutr., 30: 283-292.

FAO. - 1989. Yield and nutritional value of the commercially more important fish species. FAO Fish. Techn. Pap., 309: 1-187.

FAO/WHO. - 1991. Protein quality evaluation. Report of the Joint FAO/WHO Expert Consultation. FAO Food Nutri. Pap., 51: $1-120$.

Gall, K.L., W.S. Otwell, J.A. Koburger and H. Appledorf. - 1983. Effects of four cooking methods on the proximate mineral and fatty acid composition of fish fillets. J. Food Sci., 48: 1068-1074.

García-Arias, M.T., E.A. Pontes, M.C. García-Linares, M.C. García-Fernández and F.J. Sánchez-Muniz. - 2003. Cookingfreezing-reheating (CFR) of sardine (Sardina pilchardus) effect of different cooking and reheating procedures on the proximate and fatty acid compositions. Food Chem., 83: 349-356.

Gill, H.S. and A.H. Weatherley. - 1984. Protein, lipid and caloric contents of bluntnose minnow, Pimephales notatus Rafinesque, during growth at different temperatures. J. Fish Biol. 25: 491-500

Gokoglu, N., P. Yerlikaya and E. Cengiz. - 2004. Effects of cooking methods on the proximate composition and mineral contents of rainbow trout (Oncorhynchus mykiss). Food Chem., 84: 19-22.

Gordon, J.D.M., O.A. Bergstad, I. Figueiredo and G. Menezes. 2003. The deep-water fisheries of the Northeast Atlantic: I. Description and current trends. J. Northw. Atl. Fish. Sci., 31: $137-150$.

Gormley, T.R., P. Connolly and P. Ward. - 1994. Evaluation of deep water fish species. Farm \& Food, 4, 8-11 http://www.healingwithnutrition.com/mineral.htm, consulted on October 2008

Huynh, M.D. and D.D. Kitts. - 2009. Evaluating nutritional quality of Pacific fish species from fatty acid signatures. Food Chem., 114: 912-918.

IPQ - 1988. NP 2929 - Pescado: Determinação do teor de cloreto.

ISSFAL. - 2004. International Society for the Study of Fatty Acids and Lipids. Recommendations for intake of polyunsaturated fatty acids in healthy adults. June 2004. 22p.

Kalogeropoulos, N., N.K. Andrikopoulos and M. Hassapidou. 2004. Dietary evaluation of Mediterranean fish and molluscs pan-fried in virgin olive oil. J. Sci. Food Agric., 84: 17501758

Kjerstad, M., I. Fossen and H.M. Willemsen. - 2003. Utilization of deep sea sharks at Hatton bank in the North Atlantic. J. Northw. Atl. Fish. Sci., 31: 333-338.

Lepage, G. and C.C. Roy. - 1986. Direct transesterification of all classes of lipids in a one-step reaction. J. Lipid Res., 27: 114-119.

Love, R.M. - 1980. The Chemical Biology of Fishes. Volume 2. Advances 1968-1977. Academic Press, London.

Maier, K., T.R. Gormley, P.L. Connolly and M. Auty. - 1997. As- sessment of under-utilised fish species. Farm \& Food, 1: 30-34.

Naemmi, E.D., N. Ahmad, T.K. Al-Sharrah and M. Behbahani. 1995. Rapid and simple method for determination of cholesterol in processed food. J. AOAC Int., 78: 1522-1525.

Nunes, M.L., N.M. Bandarra and I. Batista. - 2003. Fish products: Contribution for a healthy food. Electron J. Environ. Agric. Food Chem., 2: 453-457.

Neves, A., A.R. Vieira, I. Farias, I. Figueiredo, V. Sequeira and L.S. Gordo. - 2009. Reproductive strategies in black scabbardfish (Aphanopus carbo Lowe, 1839) from NE Atlantic. Sci. Mar., 73S2: 19-31.

Oehlenschläger, J. - 2000. Cholesterol content in edible part of marine fatty pelagic fish species and other seafood. In: S.A. Georgakis (ed.), Proc. 29th WEFTA Meeting, pp 107-115. Greek Society of Food Hygienists and Technologists, Thessaloniki.

Økland, H.M.W., I.S. Stoknes, J.F. Remme, M. Kjerstad and M. Synnes. - 2005. Proximate composition, fatty acid and lipid class composition of the muscle from deep-sea teleosts and elasmobranchs. Comp. Biochem. Physiol., 140: 437-443.

Oliveira A.C.M., D.A.J. Stone, S. Plante, S. Smiley, P.J. Bechtel and R.W. Hardy. - 2008. Fish oils from Alaskan seafood processing by-products: An unexploited sustainable resource for aquaculture. World Aquac., 39: 50-51.

Ota, T., Y. Ando, H. Nakajima and A. Shibahara. - 1995. C ${ }_{20}-C_{2}$ Monounsaturated fatty acid isomers in the lipids of flathead flounder, Hippoglossoides dubius. Comp. Biochem. Physiol., 111B: 195-200

Parker, R.R. and W.E. Vanstone. - 1966. Changes in the chemical composition of central British Columbia pink salmon during early sea life. J. Fish. Res. Board Canada, 23: 1353-1384.

Rosa, R., N.M. Bandarra and M.L. Nunes. - 2007. Nutritional quality of African catfish Clarias gariepinus (Burchell 1822): a positive criterion for the future development of the European production of Siluroidei. Int. J. Food Sci. Tech., 42: 342-351.

Ruiter, A. - 1995. Contaminants in Fish. In: A. Ruiter (ed.), Fish and Fishery Products. Composition, Nutritive Properties and Stability, pp. 261-285. Wallingford, UK.

Seargent, J.R., K. Coupland and R. Wilson. - 1994. Nervonic acid and demyelinating disease. Med. Hypoth., 42: 237-242.

Shanta, N.C. and R.G. Ackman. - 1991. Fish oil tetracosenoic acid isomers and GLC analyses of polyunsaturated fatty acids. Lipids, 26: 237-239.

Sharer, K.D. - 1994. Factors affecting the proximate composition of cultured fishes with emphasis on salmonids. Aquaculture, 119: 63-88.

Sirot, V., M. Oseredczuk, N. Bemrah-Aouachria, J-L Volatier and J-C Leblanc. - 2008. Lipid and fatty acid composition of fish and seafood consumed in France: CALIPSO study. J. Food Comp. Analys., 21: 8-16.

Stowasser, G., R. McAllen, G.J. Pierce, M.A. Collins, C.F. Moffat, I.G. Priede and D.W. Pond. - 2009. Trophic position of deep-sea fish - Assessment through fatty aci and stable isotope analyses. Deep-Sea Res. I, 56: 812-826.

Suzuki, T. - 1981. Fish and Krill Protein: Processing Technology. Applied Science Publ., London.

Türkkan, A.U., S. Cakli and B. Kilinc. - 2008. Effects of cooking methods on the proximate composition and fatty acid composition of seabass (Dicentrarchus labrax, Linnaeus, 1758). Food Bioprod. Proc., 86: 163-166.

Ulbricht, T.L. and D.A.T. Southgate. - 1991. Coronary heart disease: seven dietary factors. Lancet, 338: 985-992.

Usydus, Z., J. Szlinder-Richert and M. Adamczyk. - 2009. Protein quality and amino acid profiles of fish products available in Poland. Food Chem., 112: 139-145.

Weatherley, A.H. and H.S. Gill - 1987. The Biology of Fish Growth. Academic Press, New York.

Weihrauch, J.L., L.P. Posati, B.A. Anderson and J. Exler. - 1977. Lipid conversion factors for calculating fatty acids contents in foods. JAOCS, 54: 36-40.

Scient. ed.: L.S. Gordo.

Received December 12, 2008. Accepted October 1, 2009.

Published online December 22, 2009. 